Biol. Stud. 2018: 12(2); 25-34 • https://doi.org/10.30970/sbi.1202.568

www.http://publications.Inu.edu.ua/journals/index.php/biology

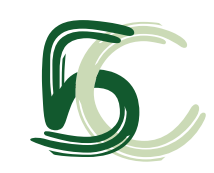

UDC $576.224 .4 ; 547 ; 615.277 .3$

\title{
EFFECTS OF NEW DERIVATIVES OF 2-AMINO-5-BENZYLTHIAZOLE ON GENOTOXICITY AND ACUTE TOXICITY IN ALLIUM BIOASSAY
}

\author{
N. S. Finiuk ${ }^{1,2}$, V. P. Hreniukh ${ }^{1}$, Yu. V. Ostapiuk ${ }^{3}$, \\ V. S. Matiychuk ${ }^{3}$, M. D. Obushak ${ }^{3}$, R. S. Stoika ${ }^{1,2,4 *}$, A. M. Babsky ${ }^{1 *}$ \\ ${ }_{1}^{1}$ Ivan Franko National University of Lviv, Biology Faculty, 4, Hrushevskyi St., Lviv 79005, Ukraine \\ e-mail: nataliyafiniuk@gmail.com \\ ${ }^{2}$ Institute of Cell Biology, NAS of Ukraine, 14-16, Drahomanov St., Lviv 79005, Ukraine \\ ${ }^{3}$ Ivan Franko National University of Lviv, Chemistry Faculty, \\ 6, Kyryl and Mefodiy St., Lviv 79005, Ukraine \\ ${ }^{4}$ Danylo Halytsky Lviv National Medical University, 69, Pekarska St., Lviv 79010, Ukraine \\ ${ }^{*}$ Corresponding author: R. S. Stoika, e-mail: stoika@cellbiol.Iviv.ua \\ A. M. Babsky, e-mail: andriy.babsky@Inu.edu.ua
}

Finiuk N. S., Hreniukh V. P., Ostapiuk Yu. V., Matiychuk V. S., Obushak M. D., Stoika R. S., Babsky A. M. Effects of new derivatives of 2-amino-5-benzylthiazole of genotoxicity and acute toxicity in Allium bioassays. Studia Biologica, 2018: 12(2); 25-34 • https://doi.org/10.30970/sbi.1202.568

We have found that new derivatives of 2-amino-5-benzylthiazole possess cytotoxic action towards human tumor cells (Finiuk et al., Biopolym. Cell, 2017; Finiuk et al., Ukr. Biochem. J., 2018). A release of the chemotherapeutic drugs into the environment may cause adverse effects towards ecosystems. To promote further these derivatives as potential anticancer agents, it was necessary to evaluate their genotoxicity and acute toxicity, namely in plants that have an important trophic level in ecosystems. To do that, we used towards plant bioassays for new derivatives of N-(5-benzyl-1,3-thiazol-2-yl)-3,5-dimethyl-1-benzofuran-2-carboxamide (compound 1) and 2,8-dimethyl-7-(3-trifluoromethylbenzyl)pyrazolo[4,3-e]thiazolo[3,2-a]pyrimidin-4-one (compound 2). Allium cepa ana-telophase assay was applied to monitor the genotoxicity of the studied compounds. Besides, the acute toxic effects such as inhibition of cell division, seed germination and growth of Allium roots were estimated. The compound $1(10 \mu \mathrm{M})$ in concentration equal to the $\mathrm{IC}_{50}$ for tumor cells, and compound 2 in $1 \mu \mathrm{M}$ (1× concentration, equal to the $\mathrm{IC}_{50}$ for tumor cells) and $10 \mu \mathrm{M}(10 \times$ concentration) did not possess acute toxicity towards Allium cepa. A significant inhibition of root growth and seed germination effects were detected at using the compound $\mathbf{1}$ only in dose that is 10 times higher than the $\mathrm{IC}_{50}$ for tumor cells. The anatelophase assay did not reveal the genotoxic effect of the compounds $1(10 \mu \mathrm{M})$ and

(C) 2018 N. S. Finiuk et al.; Published by the Ivan Franko National University of Lviv on behalf of Біологічні Студії / Studia Biologica. This is an Open Access article distributed under the terms of the Creative Commons Attribution License (http://www.budapestopenaccessinitiative.org/ and Creative Commons Attribution 4.0 License), which permits unrestricted reuse, distribution, and reproduction in any medium, provided the original work is properly cited.

ISSN 1996-4536 (print) • ISSN 2311-0783 (on-line) • Біологічні Студії / Studia Biologica • 2018 • Том 12/№2 • С. 25-34 
$2(1$ and $10 \mu \mathrm{M})$. The compounds $1(10 \mu \mathrm{M})$ and $2(1$ and $10 \mu \mathrm{M})$ did not affect the mitotic and phase (prophase, metaphase, anaphase, telophase) indices. A commercial anticancer drug Doxorubicin $(0.1$ and $1 \mu \mathrm{M})$ possessed a significant inhibitory effect on root growth and seed germination, mitotic index and enhanced a level of chromosomal aberrations in Allium cepa. The compound 1 at $10 \mu \mathrm{M}$ and compound 2 at $1 \mu \mathrm{M}$ and $10 \mu \mathrm{M}$ did not possess a significant acute toxicity (inhibition of cell division, seed germination and growth of Allium roots), did not demonstrated the genotoxic effects (induction of chromosomal aberrations) in Allium bioassay. These results give primary evidence about a possibility of using the synthetic 2-amino-5-benzylthiazole derivatives compounds 1 and $\mathbf{2}$ - as novel antineoplastic agents that will have no negative side effects in the treated plant organism. Additional experiments should be performed in order to evaluate the adverse effects of new derivatives of 2-amino-5-benzylthiazole in a vide spectrum of the concentrations for the prediction of environmental toxicity and genotoxicity of chemicals.

Keywords: 2-amino-5-benzylthiazole derivatives, genotoxicity, chromosome aberration, Allium cepa

\section{INTRODUCTION}

The inflammation and the metabolic activity can affect cell integrity via modification of nucleotide bases and/or breaking sugar-phosphate backbone [21]. Many anticancer drugs (doxorubicin, cisplatin, temozolomide) damage DNA that disrupts cell cycle resulting in its arrest and/or cell death $[10,21]$. While the other anticancer drugs (tarceva, iressa, sutent) affect DNA indirectly. The mainstream of modern chemotherapy is a targeted therapy with a direct action on the pathological cells or tissues without the effect on healthy ones. It was reported that chemotherapeutic agents may release in the environment (air, surface waters, sediments and soil) and cause adverse effects (affect the stability of ecosystems via reducing the viability of species) [16].

New thiazole derivative, namely N-(5-benzyl-1,3-thiazol-2-yl)-3,5-dimethyl-1-benzofuran-2-carboxamide (here noted as compound 1) demonstrated a toxicity against human glioblastoma U251 cells $\left(\mathrm{IC}_{50}=9.8 \pm 0.82 \mu \mathrm{M}\right)$ and human melanoma WM793 cells $\left(\mathrm{IC}_{50}=7.2 \pm 0.48 \mu \mathrm{M}\right)$ [6], while 2,8-dimethyl-7-(3-trifluoromethyl-benzyl)pyrazolo[4,3-e]thiazolo[3,2-a]pyrimidin-4-one (here noted as compound 2) demonstrated a toxicity against human leukemia cells of $\mathrm{HL}-60\left(\mathrm{IC}_{50}\right.$ was was $\left.0.09 \pm 0.008 \mu \mathrm{M}\right)$, against Jurkat and $\mathrm{K} 562$ lines $\left(\mathrm{IC}_{50}\right.$ was approximately $\left.1 \mu \mathrm{M}\right)[7]$. IC $\mathrm{I}_{50}$ of compounds 1 and 2 for pseudo-normal cells was 3.2-30 $\mu \mathrm{M}[6,7]$. Besides, it was shown that the compound 1 induced apoptosis and DNA damage, affected a transition of G2/M phase of cell cycle in human glioblastoma U251 cells [8, accepted]. Thus, the compounds 1 and 2 can be potential anticancer agents. However, the genotoxicity of these derivatives stays not studied. Furthermore, there is no information on their ecotoxicilogical effects.

That is why, studying general toxicity and genotoxicity of the anticancer drugs are important for improving their therapeutic action and environmental safety.

Various bioassays have been applied for measuring the genotoxicity of different agents. Here, cytotoxicity assay and ana-telophase test in Allium cepa were chosen for screening the acute toxic and genotoxic effects of novel compounds $\mathbf{1}$ and $\mathbf{2}$. The higher plants have an important trophic level in ecosystems [17]. The $A$. cepa was found as a convenient test system with stable number of chromosomes, visible mitotic phases for

ISSN 1996-4536 (print) • ISSN 2311-0783 (on-line) • Біологічні Студії / Studia Biologica • 2018 • Том 12/№2 • С. 25-34 
detection of genotoxins effect on the level of chromosomal abformalities [4]. Ana-telophase test in the mitotic root cells of Allium cepa is widely used plant bioassay in the genotoxicity studies. This test has been applied to investigate genotoxicity of different chemicals [3, 11, 14, 15], anticancer drugs, for example, cisplatin, 5-fluorouracil, imatinib mesylate [17], gambogic acid [20], alkylating agents (ethyl methanesulphonate), and methyl methanesulphonate [5, 14], food synthetic flavors [2] and nanoparticles [4, $12,13,16]$. Bagatini et al. also used Allium cepa test to evaluate genotoxic effects of hospital effluent in Brasil. They observed a chromatid bridges, chromosomal disruptions and micronuclei that indicating environmental toxicity of hospital effluent [1].

Besides, we have studied the impact of the synthesized thiazoles derivatives on the Allium seed germination and root growth. These parameters are commonly used in the eco-toxicological investigations [9, 11].

The aim of this study was to investigate if novel synthetic derivatives of the 2-amino-5-benzylthiazole possess an acute toxic and genotoxic action in Allium test.

\section{MATERIALS AND METHODS}

Compounds. New thiazole derivatives N-(5-benzyl-1,3-thiazol-2-yl)-3,5-dimethyl1-benzofuran-2-carboxamide (compound 1) [6] and 8-methyl-2-Me-7-[3-CF-phenilmethyl]pyrazolo[4,3-e][1,3]thiazolo[3,2-a]pyrimidin-4(2H)-ones (compound 2) [7] were synthesized at the Department of Organic Chemistry of Ivan Franko National University of Lviv, Ukraine. $10 \mathrm{mM}$ stock solutions were prepared in the Dimethyl sulfoxide (DMSO, Sigma-Aldrich, USA), and the working solutions were prepared using distilled water. The final concentrations of 2-amino-5-benzylthiazole derivatives were chosen based on the data of their relevant cytotoxic effects on tumor cells (leukemia, glioma, melanoma) [4, 7]: concentrations that corresponded to $\mathrm{IC}_{50}$ value of compounds for tumor cells were $10 \mu \mathrm{M}$ for compound 1 and $1 \mu \mathrm{M}$ - for compound 2. In addition, the concentrations that are 10 times higher $I_{50}$ for tumor cells were analyzed for identifying the damaging effects of compounds: 10x concentration of compound 1 was 100 and $10 \mu \mathrm{M}$ - for compound 2 .

Sodium azide (150 $\mu \mathrm{M}$, Sigma-Aldrich, USA) and commercial anticancer drug Doxorubicin ( 0.1 and $1 \mu \mathrm{M}$, Teva, the Netherlands) were used as a positive control compounds.

Impact of the thiazole derivatives on growth of Allium cepa. Toxicity experiments were conducted using $A$. cepa in a modified assay described in [9]. A. cepa seeds (15 per each point) were germinated on the studied solutions of the compound 1 (10 and $100 \mu \mathrm{M})$ and $2(1$ and $10 \mu \mathrm{M})$, sodium azide $(150 \mu \mathrm{M})$ and Doxorubicin $(0.1$ and $1 \mu \mathrm{M})$ for 3 days at $22{ }^{\circ} \mathrm{C}$. Distilled water was used as a negative control. The root growth and \% of inhibition of seed germination were calculated.

Allium ana-telophase chromosome aberration assay. The Allium cepa genotoxicity study was performed, as described previously [19]. The method is based on the detection of chromosomal aberrations that occur in the root of the meristema cells of Allium cepa L. germinated under the action of studied compounds at two concentrations (equal to $\mathrm{IC}_{50}$ and $10 \times \mathrm{IC}_{50}$ for tumor cells) and positive control compounds (sodium azide $(150 \mu \mathrm{M})$ and Doxorubicin $(0.1$ and $1 \mu \mathrm{M}))$. Seeds were germinated at $22{ }^{\circ} \mathrm{C}$ during 3 days. The material was fixed in a mixture (3:1) of ethanol and acetic acid (Sfera Sim, Ukraine) for $24 \mathrm{~h}$, and then stored in $70 \%$ ethanol. Roots were washed in distilled water, macerated for 10 min in $1 \mathrm{M} \mathrm{HCl}$ (Sfera Sim, Ukraine). Cells were analyzed at different stages of cell cycle at 10×10 under a light microscope (MIKMED 2, LOMO, Russian Federation). Chromosomes were colored for $15 \mathrm{~min}$ by $1 \%$ acetoorseine (Sigma-Aldrich,

ISSN 1996-4536 (print) • ISSN 2311-0783 (on-line) • Біологічні Студії / Studia Biologica • 2018 • Том 12/№2 • С. 25-34 
USA). In order to establish cyto- and genotoxicity of studied compounds, we have determined the mitotic index $(\mathrm{MI}, \%)=(\mathrm{P}+\mathrm{M}+\mathrm{A}+\mathrm{T}) /(\mathrm{I}+\mathrm{P}+\mathrm{M}+\mathrm{A}+\mathrm{T}) \times 100 \%$, prophase index $(\%)=P /(I+P+M+A+T) \times 100 \%$ and chromosomal aberrations $(C A, \%)=N /(A+T) \times 100 \%$, where $P$ is the number of cells in prophase, $M-$ in metaphase, $A-$ in anaphase, $T-$ in telophase, I - in interphase, $\mathrm{N}$ - number of chromosomal aberrations in A and T phases. We have analyzed minimal 4,000 cells per each experimental point.

Statistical analysis. All results were analyzed using GraphPad Prism 6. All data are presented as mean (M) \pm standard deviation (SD). Statistical analyses were performed using ANOVA test. $P$ value of $<0.05$ was considered as statistically significant.

\section{RESULTS AND DISCUSSION}

This is the first study of the acute toxic and genotoxic effects of new derivatives (compounds 1 and 2 ) of the thiazole. These derivatives were used at concentrations that corresponded to $\mathrm{IC}_{50}$ value of compounds for tumor cells (1× concentration of the compound 1 was $10 \mu \mathrm{M}$; of $2-1 \mu \mathrm{M})[6,7]$ and concentrations that are 10 times higher $\mathrm{IC}_{50}$ for tumor cells (10x concentration of compound 1-100 $\mu \mathrm{M}$; of $2-10 \mu \mathrm{M}$ ).

Table 1 and Fig. 1 demonstrate that the compounds 1 and 2 dose-dependently inhibited root growth. The compound 1 possessed a significant inhibition action $(25.2 \pm 0.3 \%)$ on root growth only at $10 \times$ concentration $(100 \mu \mathrm{M})$, while the effect of the compound 2 at $10 \mu \mathrm{M}$ on the inhibition of root growth was insignificant $(16.0 \pm 0.3 \%)$. The compounds 1 and 2 at $1 \times$ concentrations non-significantly inhibited root growth: compound $1(10 \mu \mathrm{M})-$ by $15.0 \pm 0.1 \%$ compared to the control, and compound $2(1 \mu \mathrm{M})-$ by $13.3 \pm 0.1 \%$.

Table1. Impact of the derivatives of 2-amino-5-benzylthiazole on root growth and seed germination in Allium cepa bioassay $(\mathrm{n}=3)$

Таблиця 1. Вплив похідних 2-аміно-5-бензилтіазолу на ріст кореня та проростання насіння цибулі Allium cepa $(\mathrm{n}=3)$

\begin{tabular}{|l|c|c|c|c|}
\hline \multicolumn{1}{|c}{ Sample } & $\begin{array}{c}\text { Root length, } \\
\mathrm{mm} \pm \mathrm{SD}\end{array}$ & $\begin{array}{c}\text { Inhibition of root } \\
\text { growth, } \% \pm \mathrm{SD}\end{array}$ & $\begin{array}{c}\text { Seed germination, } \\
\% \pm \mathrm{SD}\end{array}$ & $\begin{array}{c}\text { Inhibition of seed } \\
\text { germination, \% } \pm \mathrm{SD}\end{array}$ \\
\hline Control & $19.8 \pm 4.9$ & 0 & $91.1 \pm 3.8$ & 0 \\
\hline $\mathrm{NaN}_{3}(150 \mu \mathrm{M})$ & $12.3 \pm 2.8^{* * *}$ & $37.9 \pm 0.4^{* * *}$ & $68.9 \pm 3.8^{* *}$ & $24.4 \pm 1.4^{* *}$ \\
\hline Dox, $0.1 \mu \mathrm{M}$ & $12.0 \pm 1.8^{* * *}$ & $39.4 \pm 0.3^{* * *}$ & $62.2 \pm 3.8^{* * *}$ & $31.7 \pm 2.0^{* * *}$ \\
\hline Dox, $1 \mu \mathrm{M}$ & $11.2 \pm 1.7^{* * *}$ & $43.2 \pm 0.3^{* * *}$ & $53.3 \pm 6.3^{* * *}$ & $41.5 \pm 4.9^{* * *}$ \\
\hline $\mathrm{DMSO}, 0.01 \%$ & $17.7 \pm 2.0$ & $10.6 \pm 0.6$ & $86.7 \pm 6.7$ & $4.9 \pm 0.4$ \\
(solvent) & $16.8 \pm 2.4$ & $15.0 \pm 0.1$ & $82.2 \pm 3.8$ & $9.7 \pm 0.5$ \\
\hline $1,10 \mu \mathrm{M}$ & $14.8 \pm 3.3^{* *}$ & $25.2 \pm 0.3^{* *}$ & $75.6 \pm 3.8^{* *}$ & $17.1 \pm 0.9^{* *}$ \\
\hline $1,100 \mu \mathrm{M}$ & $17.2 \pm 4.1$ & $13.3 \pm 0.1$ & $84.4 \pm 3.8$ & $7.3 \pm 0.3$ \\
\hline $2,1 \mu \mathrm{M}$ & $16.6 \pm 3.4$ & $16.0 \pm 0.3$ & $77.8 \pm 3.8^{*}$ & $14.6 \pm 0.7^{*}$ \\
\hline $2,10 \mu \mathrm{M}$ & & &
\end{tabular}

Comments: * $-\mathrm{P}<0.05 ;{ }^{* *}-\mathrm{P}<0.01 ;{ }^{* *}-\mathrm{P}<0.001$

Примітки: * $-\mathrm{P}<0,05 ;{ }^{* *}-\mathrm{P}<0,01 ;{ }^{* *}-\mathrm{P}<0,001$

We also revealed the inhibition effect of the compounds 1 and 2 on seed germination. A significant effect on seed germination was detected under the action of the compounds in doses that were 10 times higher than the $\mathrm{IC}_{50}$ (Table 1 and Fig. 1).

ISSN 1996-4536 (print) • ISSN 2311-0783 (on-line) • Біологічні Студії / Studia Biologica • 2018 • Том 12/№2 • C. 25-34 
The positive control agents sodium azide $(150 \mu \mathrm{M})$ and commercial anticancer drug Doxorubicin $(0.1$ and $1 \mu \mathrm{M})$ caused a significant inhibitory effect on root growth and seed germination (Table 1 and Fig. 1). For comparison, anticancer agents cisplatin at $\geq 1 \mu \mathrm{M}$ and 5-flurouracil at $\geq 1 \mu \mathrm{M}$ significantly inhibited the root growth of Allium cepa [16].

A

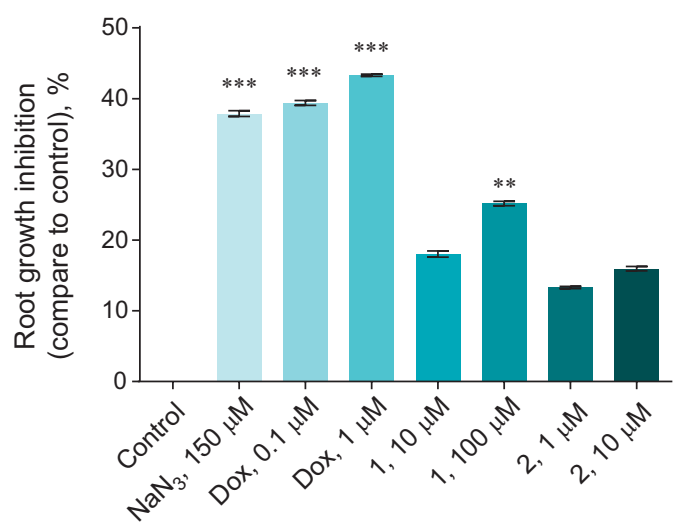

$B$

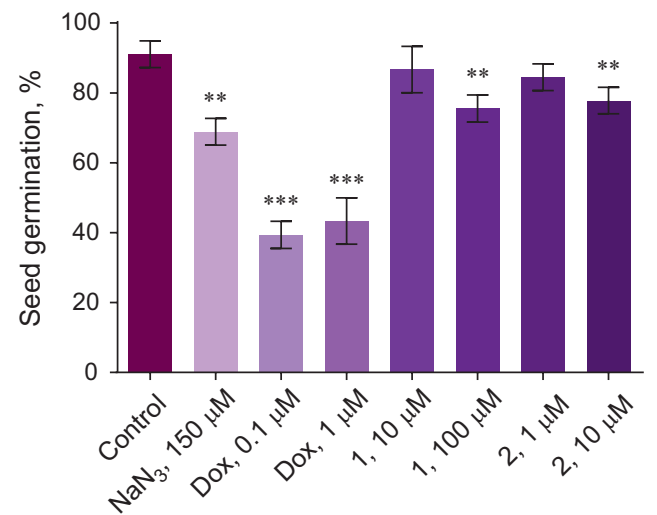

Fig. 1. Impact of 2-amino-5-benzylthiazole derivatives on root growth $(A)$ and seed germination $(B)$ in Allium cepa bioassay. Seeds were germinated on the studied solutions of compounds $1(10$ and $100 \mu \mathrm{M})$, $2(1$ and $10 \mu \mathrm{M})$, and $\mathrm{NaN}_{3}(150 \mu \mathrm{M})$ at $22{ }^{\circ} \mathrm{C}$ for three days. Inhibition of root growth (root growth inhibition in control was identified as $0 \%$ ) and seed germination were calculated to identify the acute toxicity of the compounds. ${ }^{*}-\mathrm{P}<0.05 ;{ }^{* *}-\mathrm{P}<0.01$

Рис. 1. Вплив похідних 2-аміно-5-бензилтіазолу на ріст кореня $(A)$ та проростання насіння $(B)$ цибулі Allium сера. Насіння цибулі пророщували у розчинах досліджуваних речовин 1 (10 та $100 \mu \mathrm{M})$, $2(1$ та $10 \mu \mathrm{M})$ і $\mathrm{NaN}_{3}(150 \mu \mathrm{M})$ за $22{ }^{\circ} \mathrm{C}$ протягом трьох днів. Показник інгібування росту кореня (показник у контролі прирівняно до 0 \%) та проростання насіння використовували для визначення гострої токсичності речовин. ${ }^{*}-\mathrm{P}<0,05 ;{ }^{* \star}-\mathrm{P}<0,01$

The results of the ana-telophase assay did not reveal changies in the mitotic index in Allium meristematic cells under the action of the compounds $1(10 \mu \mathrm{M})$ and $2(1 \mu \mathrm{M})$. A significant decrease in the mitotic index was found only at the action of compound 1 used in higher dose $(100 \mu \mathrm{M})$ and positive control agents (sodium azide $(150 \mu \mathrm{M})$ and Doxorubicin (0.1 and $1 \mu \mathrm{M})$, Table 2$)$.

The 2-amino-5-benzylthiazole derivatives did not cause changes in the prophase, metaphase, anaphase, and telophase index (Table 2). Doxorubicin at $1 \mu \mathrm{M}$ significantly affected prophase, metaphase, anaphase, and telophase index (Table 2). It was reported that anticancer drugs inhibited the cell division of Allium cepa. Significant effects were detected under cisplatin at $\geq 1 \mu \mathrm{M}$ [16], imatinib mesylate at $\geq 10 \mu \mathrm{M}$ [17], 5-flurouracil and etoposide at $\geq 50 \mu \mathrm{M}$ [16]. An inhibition of the mitotic activity is one of the parameters of estimating cytotoxicity of various compounds. We suggested that studied compounds demonstrated their anti-proliferative activity via a suppression of DNA synthesis or cell cycle arrest in G2 phase [18, 20].

Genotoxic properties of compounds resulted structural or numerical chromosomal aberrations [18, 20]. The level of chromosomal aberrations in control was about $2.3 \pm 0.9 \%$. Some amount of chromosomal aberrations in control could be explained by spontaneous mutations in the meristematic cells [20]. We detected insignificant change in the aberration level to $2.8 \pm 1.2 \%$ for compound 1 at $10 \mu \mathrm{M}$, to $2.6 \pm 1.2 \%$ for compound 2 at $1 \mu \mathrm{M}$ and $2.9 \pm 1.2 \%$ for compound 2 at $10 \mu \mathrm{M}$. There was also no significant 
change in the value of the chromosomal aberrations to $3.1 \pm 1.5 \%$ at the action of the compound $1(100 \mu \mathrm{M})$, compared with the negative control (Table 3, Fig. 2).

It should be noted that sodium azide and Doxorubicin (positive control agents) induced much more significant changes in the values of the mitotic index and chromosomal aberrations (Tables 2 and 3).

Table 2. Changes in the mitotic and phase (prophase, metaphase, anaphase, telophase) index under the action of 2-amino-5-benzylthiazole derivatives $(n=3)$

Таблиця 2. Мітотичний і фазовий (про-, мета-, ана-, телофазний) індекс за дії похідних 2-аміно-5-бензилтіазолу $(\mathrm{n}=3)$

\begin{tabular}{|c|c|c|c|c|c|c|}
\hline \multirow{2}{*}{ Sample } & \multicolumn{4}{|c|}{ Phase index, $\% \pm$ SD } & \multicolumn{2}{|c|}{ MI } \\
\hline & P & M & A & $\mathrm{T}$ & $\% \pm \mathrm{SD}$ & $\%$ to ctrl \\
\hline Control & $86.7 \pm 1.5$ & $3.4 \pm 0.3$ & $6.2 \pm 1.3$ & $3.7 \pm 0.1$ & $12.9 \pm 0.8$ & 100 \\
\hline $\mathrm{NaN}_{3}(150 \mu \mathrm{M})$ & $88.0 \pm 0.9$ & $3.3 \pm 0.1$ & $5.2 \pm 0.7$ & $3.6 \pm 0.2$ & $8.8 \pm 0.6^{* *}$ & 68.4 \\
\hline Dox, $0.1 \mu \mathrm{M}$ & $89.4 \pm 0.5$ & $2.9 \pm 0.3$ & $4.7 \pm 0.4$ & $3.0 \pm 0.2^{* *}$ & $8.6 \pm 0.8^{* *}$ & 66.9 \\
\hline Dox, $1 \mu \mathrm{M}$ & $90.4 \pm 0.2^{*}$ & $2.6 \pm 0.3^{*}$ & $4.1 \pm 0.2^{*}$ & $2.9 \pm 0.2^{\star *}$ & $7.6 \pm 0.2^{* * *}$ & 59.0 \\
\hline $\begin{array}{l}\text { DMSO, } 0.01 \% \\
\text { (solvent) }\end{array}$ & $88.4 \pm 0.2$ & $3.1 \pm 0.2$ & $5.2 \pm 0.4$ & $3.4 \pm 0.4$ & $12.5 \pm 0.5$ & 97.0 \\
\hline $1,10 \mu \mathrm{M}$ & $87.2 \pm 2.0$ & $3.4 \pm 0.3$ & $6.0 \pm 1.1$ & $3.4 \pm 0.6$ & $11.4 \pm 0.9$ & 88.4 \\
\hline $1,100 \mu \mathrm{M}$ & $86.5 \pm 2.0$ & $3.7 \pm 0.5$ & $6.7 \pm 1.5$ & $3.1 \pm 0.2$ & $10.9 \pm 0.5^{*}$ & 84.1 \\
\hline $2,1 \mu \mathrm{M}$ & $88.2 \pm 0.3$ & $3.8 \pm 0.2$ & $5.1 \pm 0.6$ & $2.9 \pm 0.3$ & $11.8 \pm 0.8$ & 91.2 \\
\hline $2,10 \mu \mathrm{M}$ & $87.9 \pm 1.6$ & $3.2 \pm 0.6$ & $5.7 \pm 0.7$ & $3.2 \pm 0.6$ & $11.1 \pm 0.9$ & 85.8 \\
\hline \multicolumn{7}{|c|}{ 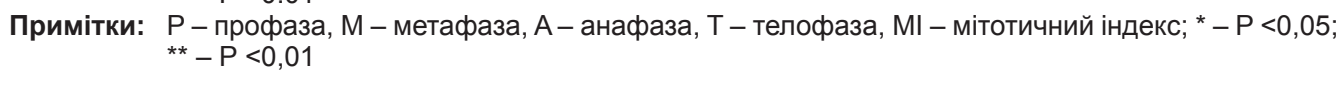 } \\
\hline \multicolumn{7}{|c|}{$\begin{array}{l}\text { Table 3. Impact of 2-amino-5-benzylthiazole derivatives on the induction of chromo- } \\
\text { somal aberrations in Allium cepa }(n=3)\end{array}$} \\
\hline \multicolumn{7}{|c|}{$\begin{array}{l}\text { Таблиця 3. Вплив похідних 2-аміно-5-бензилтіазолу на частоту хромосомних аберацій } \\
\text { у клітинах Allium cepa }(\mathbf{n}=3)\end{array}$} \\
\hline \multirow{2}{*}{ Sample } & \multicolumn{4}{|c|}{ Chromosomal aberrations, \% } & \multirow{2}{*}{\multicolumn{2}{|c|}{$\%$ of total aberrations ( \pm SD) }} \\
\hline & Fragments & Bridge & & her & & \\
\hline Control & 0.6 & 1.7 & \multicolumn{2}{|c|}{ - } & \multicolumn{2}{|c|}{$2.3 \pm 0.9$} \\
\hline $\mathrm{NaN}_{3}(150 \mu \mathrm{M})$ & 0.8 & 4.4 & \multicolumn{2}{|c|}{1.7} & $6.9 \pm 1$ & \\
\hline Dox, $0.1 \mu \mathrm{M}$ & 1.7 & 2.4 & & .7 & $4.8 \pm 0$ & \\
\hline Dox, $1 \mu \mathrm{M}$ & 2.6 & 4.6 & & .7 & $8.9 \pm 1$ & \\
\hline $\begin{array}{l}\text { DMSO, } 0.01 \% \\
\text { (solvent) }\end{array}$ & - & 2.4 & & - & $2.4 \pm 1$ & \\
\hline $1,10 \mu \mathrm{M}$ & - & 1.5 & & 3 & $2.8 \pm 1$ & \\
\hline $1,100 \mu \mathrm{M}$ & 1.9 & 0.7 & & 6 & $3.1 \pm 1$ & \\
\hline $2,1 \mu \mathrm{M}$ & 0.7 & 1.9. & & - & $2.6 \pm 1$ & \\
\hline $2,10 \mu \mathrm{M}$ & 0.7 & 2.2 & & - & $2.9 \pm 1$ & \\
\hline
\end{tabular}

Comment: ${ }^{* *}-\mathrm{P}<0.01$

Примітка: ${ }^{* *}-\mathrm{P}<0,01$

ISSN 1996-4536 (print) • ISSN 2311-0783 (on-line) • Біологічні Студії / Studia Biologica • 2018 • Том 12/№2 • С. 25-34 


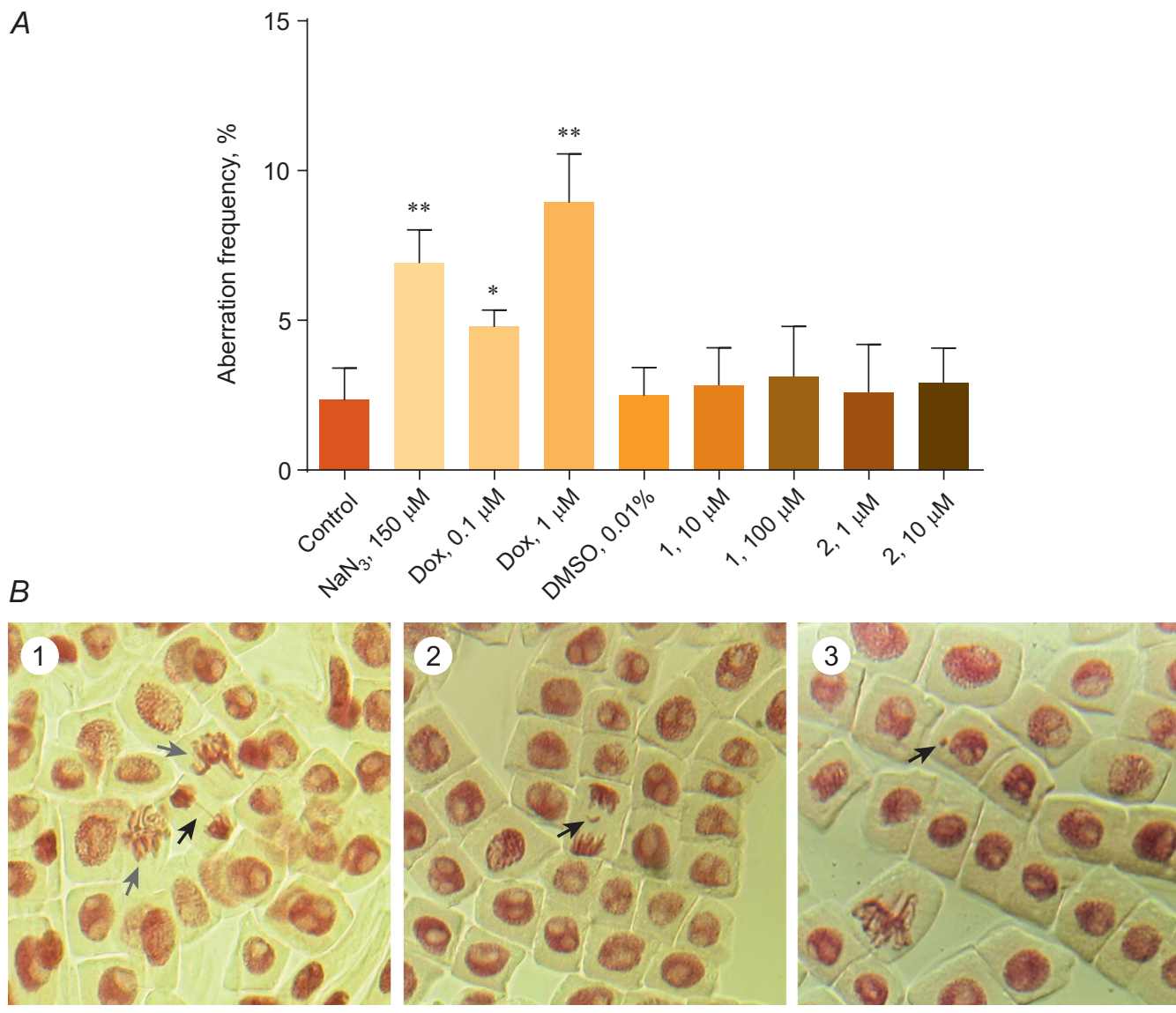

Fig. 2. Induction of chromosomal aberrations $(A)$, and abnormal chromosomes $(B)$ in Allium cepa meristema root cells by the derivatives of 2-amino-5-benzylthiazole: 1 - bridge (identified by black arrow) and sticky metaphase (identified by grey arrow); 2 - fragment (identified by black arrow); 3 - micronuclei under $\mathrm{NaN}_{3}$ effect (identified by black arrow) at $10 \times 10$. ${ }^{* *}-\mathrm{P}<0.01$

Рис. 2. Частота хромосомних аберацій $(A)$ і аномалії розходження хромосом $(B)$ у клітинах меристеми корінців Allium сера за дії похідних 2-аміно-5-бензилтіазолу: 1 - міст (чорна стрілка) і анормальна метафраза (сірі стрілки); 2 - фрагмент (чорна стрілка); 3 - мікроядро за дії $\mathrm{NaN}_{3}$ (чорна стрілка) за збільшення 10×10. ** $-\mathrm{P}<0,01$

The compound 1 at $1 \times$ concentration $(10 \mu \mathrm{M})$ and compound 2 at both $1 \times$ and $10 \times$ concentrations ( 1 and $10 \mu \mathrm{M}$, respectively) did not demonstrate acute toxicity in Allium cepa. A significant inhibition of root growth and seed germination were detected at the action of the compound 1 used at concentration that was 10 times higher than the $I C_{50}$. There was no effect of the compounds 1 and 2 revealed as the chromosomal aberrations at analyses of Allium cepa chromosomes at different phases of cell cycle (prophase, metaphase, anaphase, and telophase). The compound 1 at $100 \mu \mathrm{M}(10 \times$ concentration) significantly changed the mitotic index. We predict that release of compounds 1 and 2 will not cause the adverse effects in plants as the environmental concentrations of the antineoplastic drugs (5-fluorouracil, cisplatin, etoposide and vincristine) were mostly 4-5 orders of quantity lower as that cause acute toxic and/or genotoxic effects in higher plants [16].

ISSN 1996-4536 (print) • ISSN 2311-0783 (on-line) • Біологічні Студії / Studia Biologica • 2018 • Том 12/№2 • C. 25-34 
It was reported that the responses of higher plants, animals and other organisms to the drug release strongly differ [16]. Based on these, data we plan to perform additional experiments in order to evaluate the adverse effects of new derivatives of 2-amino5 -benzylthiazole in vide spectrum of the concentrations to the environment and to assess their mutagenic potential.

In conclusion, the compound 1 at $10 \mu \mathrm{M}$ and compound 2 at $1 \mu \mathrm{M}$ and $10 \mu \mathrm{M}$ did not possess a significant acute toxicity, neither demonstrated the genotoxic effects in Allium bioassay. We suggest that the concentrations of new 2-amino-5-benzylthiazole derivatives in soil or waters will not reach the levels required to induce acute toxic or genotoxic effects at least in plants.

\section{ACKNOWLEDGEMENTS}

This study was supported by the grant 0116 U001533 (2016-2018) funded by the budget of Ukraine.

1. Bagatini M. D., Vasconcelos T. G., Laughinghouse H. D., Martins A. F., Tedesco S. B. Biomonitoring hospital effluents by Allium cepa L. test. Bull. Environ. Contam. Toxicol, 2009; 82: 590-592.

[DOI: https://doi.org/10.1007/s00128-009-9666-z; PMID: 19224103; Google Scholar]

2. Bodnar I.V., Zubko O.S., Shcherbakova O.V., Gorbulinska S.M., Bodnar L.S. Detection of changes in chromosomal level in eukaryotic organisms under the influence of food synthetic flavors and correcting them with vitamin chemioprotectors. Factors in Experimental Evolution of Organisms, 2016; 18: 67-71. (In Ukrainian).

[Google Scholar]

3. Braga A. L., de Meneses A. P. M., Santos J. V. O., Dos Reis A. C., de Lima R. M. T., da Mata A., Paz M., Alves L., Shaw S., Uddin S. J., Rouf R., Das A. K., Dev S., Shil M. C., Shilpi J. A., Khan I. N., Islam M. T., Ali E. S., Mubarak M. S., Mishra S. K., E. Sousa J. M. C., MeloCavalcante A. A. C. Toxicogenetic study of omeprazole and the modulatory effects of retinol palmitate and ascorbic acid on Allium cepa. Chemosphere, 2018; 204: 220-226.

[DOI: https://doi.org/10.1016/j.chemosphere.2018.04.021; PMID: 29656158; Google Scholar]

4. Chaudhary S., Chauhan P., Kumar R., Bhasin K.K. Toxicological responses of surfactant functionalized selenium nanoparticles: A quantitative multi-assay approach. Sci. Total. Environ, 2018; 643: 1265-1277.

[DOI: https://doi.org/10.1016/j.scitotenv.2018.06.296; Google Scholar]

5. Fabarius A., Giehl M., Frank O., Duesberg P., Hochhaus A., Hehlmann R., Seifarth W. Induction of centrosome and chromosome aberrations by imatinib in vitro. Leukemia, 2005; 19: 1573-1578.

[DOI: https://doi.org/10.1038/sj.leu.2403861; PMID: 15990860; Google Scholar]

6. Finiuk N.S., Hreniuh V.P., Ostapiuk Yu.V., Matiychuk V.S., Frolov D.A., Obushak M.D., Stoika R.S., Babsky A.M. Antineoplastic activity of novel thiazole derivatives. Biopolym. Cell, 2017; 33 (2):135-146.

[DOI: https://doi.org/10.7124/bc.00094B; Google Scholar]

7. Finiuk N. S., Ostapiuk Yu. V., Hreniukh V.P., Shalai Ya. R., Matiychuk V. S., Obushak M. D., Stoika R. S., Babsky A. M. Evaluation of antiproliferative activity of pyrazolothiazolopyrimidine derivatives. Ukr. Biochem. J, 2018; 90(2): 25-32.

[DOI: https://doi.org/10.15407/ubj90.02.025]

8. Finiuk N., Klyuchivska O., Ivasechko I., Hreniukh V., Ostapiuk Yu., Shalai Ya., Panchuk R., Matiychuk V., Obushak M., Stoika R., Babsky A. Pro-apoptotic effects of novel thiazole derivative towards human glioma cells. Anti-Cancer Drugs, 2018, accepted.

9. Fiskesjo G. Allium test. Methods Mol. Biol, 1995; 43: 119-127. [DOI: https://doi.org/10.1385/0-89603-282-5:119; PMID: 7550639; Google Scholar]

ISSN 1996-4536 (print) • ISSN 2311-0783 (on-line) • Біологічні Студії / Studia Biologica • 2018 • Том 12/№2 • C. 25-34 
10. Helleday T., Petermann E., Lundin C., Hodgson B., Sharma R.A. DNA repair pathways as targets for cancer therapy. Nat. Rev. Cancer, 2008; 8(3): 193-204.

[DOI: https://doi.org/10.1038/nrc2342; PMID: 18256616; Google Scholar]

11. Leme D. M., Marin-Morales M. A. Allium cepa test in environmental monitoring: a review on its application. Mut. Res, 2009; 682: 71-81.

[DOI: https://doi.org/10.1016/j.mrrev.2009.06.002; PMID: 19577002; Google Scholar]

12. Mangalampalli B., Dumala N., Grover P. Allium cepa root tip assay in assessment of toxicity of magnesium oxide nanoparticles and microparticles. J. Environ. Sci. (China), 2018; 66: 125-137.

[DOI: https://doi.org/10.1016/j.jes.2017.05.012; PMID: 29628079; Google Scholar]

13. Manna I., Bandyopadhyay M. Engineered nickel oxide nanoparticles affect genome stability in Allium cepa (L.). Plant Physiol. Biochem, 2017; 121: 206-215.

[DOI: https://doi.org/10.1016/j.plaphy.2017.11.003; PMID: 29136573; Google Scholar]

14. Mazzeo D.E., Fernandes T.C., Marin-Morales M.A. Cellular damages in the Allium cepa test system, caused by BTEX mixture prior and after biodegradation process. Chemosphere, 2011; 85(1): 13-18.

[DOI: 10.1016/j.chemosphere.2011.06.056; PMID: 21741065; Google Scholar]

15. Mehrian S. K., De Lima R. Nanoparticles cyto and genotoxicity in plants: Mechanisms and abnormalities. Environmental Nanotechnology, Monitoring \& Management. 2016; 6: 184-193. [DOI: 10.1016/j.enmm.2016.08.003; Google Scholar]

16. Misik M., Pichler C., Rainer B., Filipic M., Nersesyan A., Knasmueller S. Acute toxic and genotoxic activities of widely used cytostatic drugs in higher plants: Possible impact on the environment. Environ. Res, 2014; 135: 196-203.

[DOI: https://doi.org/10.1016/j.envres.2014.09.012; PMID: 25282277; Google Scholar]

17. Pichler C., Filipic M., Kundi M., Rainer B., Knasmueller S., Misik M. Assessment of genotoxicity and acute toxic effect of the imatinib mesylate in plant bioassays. Chemosphere, 2014; 115: 54-58.

[DOI: https://doi.org/10.1016/j.chemosphere.2014.01.010; PMID: 24560280; Google Scholar]

18. Prajitha V., Thoppil J.E. Genotoxic and antigenotoxic potential of the aqueous leaf extracts of Amaranthus spinosus Linn. using Allium cepa assay. South African Journal of Botany, 2015; 102: 18-25.

[DOI: https://doi.org/10.1016/j.sajb.2015.06.018; Google Scholar]

19. Rank J., Nielsen M. H. A modified Allium test as a tool in the screening of the genotoxicity of complex mixtures. Hereditas, 1993; 118: 49-53.

[DOI: https://doi.org/10.1111/j.1601-5223.1993.t01-3-00049.x; Google Scholar]

20. Shetty A., Venkatesh T., Suresh P.S., Tsutsumi R. Exploration of acute genotoxic effects and antigenotoxic potential of gambogic acid using Allium cepa assay. Plant Physiol. Biochem, 2017; 118: 643-652.

[DOI: https://doi.org/10.1016/j.plaphy.2017.08.005; PMID: 28806720; Google Scholar]

21. Swift L. H., Golsteyn R. M. Genotoxic anti-cancer agents and their relationship to DNA damage, mitosis, and checkpoint adaptation in proliferating cancer cells. Int. J. Mol. Sci, 2014; 15(3): 3403-3431.

[DOI: https://doi.org/10.3390/ijms15033403; PMID: 24573252; Google Scholar]

\title{
ВПЛИВ НОВИХ ПОХІДНИХ 2-АМІНО-5-БЕНЗИЛТІАЗОЛУ НАГЕНОТОКСИЧНІСТЬ I ГОСТРУ ТОКСИЧНІСТЬ В ALLIUM TECTI
}

\author{
Н. С. Фінюк ${ }^{1,2}$, В. П. Гренюх ${ }^{1}$, Ю. В. Остап'юк, В. С. Матійчук', \\ М. Д. Обушак ${ }^{3}$ Р. С. Стойка', ${ }^{1,4 *}$, А. М. Бабський ${ }^{1 *}$ \\ 1 Львівський національний університет імені Івана Франка, біологічний фракультет \\ вул. Грушевського, 4, Львів 79005, Україна \\ e-mail: nataliyafiniuk@gmail.com
}


2 Інститут біології клітини НАН України, вул. Драгоманова, 14/16, Львів 79005, Україна

${ }^{3}$ Львівський національний університет імені Івана Франка, хімічний фракультет вул. Кирила і Мефродія, 6, Львів 79005, Україна

4 Львівський національний медичний університет імені Данила Галицького вул. Пекарська, 69, Львів 79010, Україна

*Кореспондуючі автори: P. C. Стойка, e-mail: stoika@cellbiol.Iviv.ua A. М. Бабський, e-mail: andriy.babsky@Inu.edu.ua

Встановлено, що нові похідні 2-аміно-5-бензилтіазолу мали токсичну дію щодо пухлинних клітин різного тканинного походження (Finiuk et al., Biopolym. Cell, 2017; Finiuk et al., Ukr. Biochem. J., 2018). Вивільнення хіміотерапевтичних препаратів у навколишнє середовище може спричинити несприятливий вплив на екосистеми. Для подальшого впровадження цих похідних як потенційних протипухлинних агентів необхідно з'ясувати питання їхньої генотоксичності й цитотоксичного впливу на рослини, які виконують важливу трофічну функцію в екосистемах. Метою цієї роботи було оцінити потенційну генотоксичну активність нових похідних N-(5-бензил-1,3тіазол-2-іл)-3,5-диметил-1-бензофуран-2-карбоксамід (1) і 2,8-диметил-7-(3-трифторметил-бензил)піразоло[4,3-е]тіазоло [3,2-а]піримідин-4-он (2). У роботі використовували Allium сера ана-телофазний тест для визначення генотоксичності досліджуваних речовин. Також оцінювали гострі токсичні ефекти за показниками інгібування поділу клітин, проростання насіння та росту коренів Allium сера. Речовина 1 (10 мкМ) і речовина 2 (1 і 10 мкM) не спричиняли цитотоксичного ефекту щодо A. сера. Речовина 1 у концентрації 100 мкМ, яка в 10 разів перевищує значення $\mathrm{IC}_{50}$ для пухлинних клітин, спричиняла достовірне інгібування росту коренів і пригнічення проростання насіння цибулі. Результати анателофазного аналізу вказують на відсутність генотоксичної дії речовин 1 у концентрації 10 мкМ та 2 у концентраціях 1 і 10 мкМ. Речовини 1 (10 мкМ) і 2 (1 і 10 мкМ) не індукують зменшення мітотичного індексу та не впливають на про-, мета-, ана- і телофазний індекси. Комерційно доступний протипухлинний препарат Доксорубіцин (0,1 і 1 мкМ) достовірно пригнічував проростання насіння Allium сера, інгібував ріст коренів, мітотичний рівень і підвищував рівень хромосомних аберацій. Речовини 1 і 2 у діапазоні концентрацій, які відповідають значенню $\mathrm{IC}_{50}$ для пухлинних клітин, а також 2 у дозі, яка в 10 разів перевищує значення $\mathrm{IC}_{50}$ для пухлинних клітин, не проявляли цитотоксичну (інгібування поділу клітин, проростання насіння і росту коренів Allium сера) та генотоксичну активності (підвищення рівня хромосомних аберацій) в Allium тесті. Одержані результати дають первинну інформацію про можливість використання синтетичних похідних 2-аміно5-бензилтіазолу - сполук 1 і 2 - як нових антинеопластичних чинників, що не матимуть негативних побічних впливів на рослини. Необхідно провести додаткові експерименти для оцінки несприятливого впливу нових похідних 2-аміно-5-бензилтіазолу в широкому спектрі концентрацій для прогнозування екологічної токсичності й генотоксичності досліджуваних речовин.

Ключові слова: похідні 2-аміно-5-бензилтіазолу, генотоксичність, хромосомні аберації, Allium сера

Одержано: 10.08.2018

ISSN 1996-4536 (print) • ISSN 2311-0783 (on-line) • Біологічні Студії / Studia Biologica • 2018 • Том 12/№2 • C. 25-34 